\title{
RELATIONSHIP BETWEEN YOUNG GENERATION AND PARENT'S AND GRAND PARENT'S GENERATION
}

\section{[VZTAH NASTUPUJICI GENERACE KE GENERACI STARSI, RODICU A PRARODICU]}

\author{
Jiri Semrad - Blanka Jirkovska - Lenka Emrova
}

doi: 10.18355/PG.2018.7.2.10

\begin{abstract}
The issue of intergenerational relations, especially intergenerational relationships within coexistence in one family, is a multidisciplinary actuall topic. Every generation has its own specific view of the world, and these views may be diametrically different due to the different experiences and habits of individual generations. The aim of this paper is to describe and classify the relationship of 13-15 year old children with the older generation with the support of literature. First, we analyze available literature on intergenerational relations and characterize individual generations in terms of their differences. The empirical survey is quantitative in nature and focuses on the analysis of the relationship of the young generation to the older one. The research was attended by 324 children aged 13-14 from elementary schools in the Ústecký, Pardubický, Zlínský and Trnava regions. A questionnaire with predominantly closed questions was used to collect the data. The collection of empirical data took place between 2015 and 2016. Subsequently, the data were statistically evaluated. The results of the empirical survey point to the fact that most of the younger generation has a positive relationship with the older generation and that the older generation is a patterns for them. The research also pointed out that material background, support, and protection are the main motivations of children to appreciate older people. Research has not confirmed the fact that the young generation is mainly devoted to digital technology in their free time, and it was surprising to find that the parents place great emphasis on the relationship of the young generation to fauna and flora, the fulfillment of duties and the relationship to home. In the above-mentioned points, the profile of the respondents, including the sites from which they came from, was shown. More worrying, however, is that more than half of respondents is not systematically and regularly involved in activities that are the subject of their deeper interest.
\end{abstract}

\section{Key words}

Generation, intergenerational relationships, family, pubescence, educational style, values, patterns

\section{Anotácia}

Problematika mezigeneračních vztahů, zejména pak mezigeneračních vztahů $\mathrm{v}$ rámci soužití $\mathrm{v}$ jedné rodině, je téma multidisciplinární a stále aktuální. Každá generace má svůj specifický pohled na svět a tyto pohledy se 
vzhledem k rozdílným zkušenostem jednotlivých generací a zvykům jejich doby mohou diametrálně lišit. Cílem tohoto článku je s oporou literatury popsat a klasifikovat vztah $13-15$ ti letých dětí ke starší generaci. Nejprve analyzujeme dostupnou literaturu $\mathrm{k}$ problematice mezigeneračních vztahů a charakterizujeme jednotlivé generace z pohledu jejich odlišností. Empirické šetření je kvantitativní povahy a je zaměřeno na analýzu vztahu mladé generace ke starší. Výzkumu se účastnilo 324 dětí ve věku 13-14 let ze ZŠ Ústeckého, Pardubického, Zlínského, a Trnavského kraje. Pro sběr dat byl použit dotazník s převážně uzavřenými otázkami. Sběr empirických dat probíhal v období 2015-2016. Následně byla data statisticky vyhodnocena. Výsledky empirického šetření poukazují na to, že většina mladé generace má pozitivní vztah ke starší generaci, a že je pro ně vzorem. Dále výzkum poukázal na to, že hlavní motivací je materiální zázemí, opora a ochrana. Výzkum nepotvrdil skutečnost, že se mladá generace věnuje ve svém volném čase především digitálním technologiím, a překvapivé bylo i zjištění, že rodiče kladou velký důraz na vztah mladé generace $\mathrm{k}$ fauně a flóře, $\mathrm{k}$ plnění povinností a vztahu $\mathrm{k}$ domovu. Ve výše uvedených bodech se zřejmě projevil profil respondentů, včetně lokalit, z nichž pocházeli. Více znepokojující je však skutečnost, že více jak polovina respondentů se nevěnuje systematicky a pravidelně nějaké činnosti, která by byla předmětem jejich hlubšího zájmu.

\section{Kl’účové slová}

Generace, mezigenerační vztahy, rodina, pubescence, výchovný styl, hodnoty, identifikační vzory

Uvod

Společenskovědní výzkumy z posledních let ukazují, že se značně proměnilo pojetí vzorů u mladé generace. Jestliže ještě nedávno to byly zejména tzv. celebrity z oblasti popové hudby, z filmových rolí apod., těžiště se přeneslo na tzv. youtubry ze sociálních sítí. Lze předpokládat, že se proto i nově vyvinul vztah mezi nastupující a starší generací.

Vztah mezi generacemi je téma multidisciplinární, a i když je středem pozornosti odborníků již několik desítek let, je stále aktuální. Této problematice se věnují odborníci z oblasti psychologie, pedagogiky, sociologie, ale z širšího pohledu i filozofie. Na toto téma existuje a stále probíhá celá řada empirických výzkumů, ze kterých budeme částečně vycházet a budeme se snažit propojit různé úhly pohledu.

Proč se vůbec zabýváme problémem vztahu mládeže ke starším lidem? Odborná společenskovědní literatura se shoduje v tom, že mladá generace vnímá svět a zejména sociální svět prostřednictvím vzorů, s nimiž se identifikuje (např. Sak (2000, 2008), Kolesárová (2016), Stašová, Slaninová, Junová (2015), Nakonečný (1999), Slaměník (2008)). Zároveň upozorňují na to, že mladý člověk se chová tak, jako by se chovala osoba, s níž se identifikuje, a které vnímá jako sobě podobné. Vzhledem $\mathrm{k}$ tomu, že s prvními vzory se mladý člověk setkává doma $v$ rodině, protože ta mu zajištuje první kontakt $\mathrm{s}$ okolním světem, stojí na počátku socializačně výchovného procesu, zajímá nás, i jaké místo ve vztazích ke starším lidem 
zaujímají u mladé generace rodiče a prarodiče. Podle Bandury (1986) děti napodobují především rodiče.

Podle Gráce (1990) lze vliv vzorů chápat v několika rovinách: 1. vzorem může být jakákoliv osoba z okolí i z prostředí; 2 . vzorem může být osoba, kterou mladý člověk oceňuje, ale přitom netouží napodobit tuto osobu, přesto, že ji oceňuje; 3. vzorem může pro mladého člověka být osoba, kterou mladý člověk oceňuje a touží být jako on (ona), ale přistupuje k ní racionálně a kriticky; 4. Vzor může být mladým člověkem chápán jako idol, z axiologického hlediska tedy stojící nejvýš, mladý člověk tuto osobu chce napodobovat, protože je jí nadšen, uctívá ji, zbožňuje ji, často i nekriticky.

Za generaci považujeme souhrnné označení lidí narozených a žijících přibližně ve stejném časovém období (zpravidla se uvádí 20 let, i když někteří badatelé, např. $P$. Sak konstatují, že zásadními sociálně ekonomickými změnami ve společnosti se časové údobí zkrátilo na 10 let), kteří přísluší k určitému typu technického zařizení, způsobu života, vyznávaných hodnot, určité sociálně ekonomické vývojové etapy společnosti. Často se význam slova generace kryje s označením nějakého období (válečná generace, generace Husákových dětí, generace Havlových dětí). Generace lidí jsou spojené věkem, epochou, hodnotami, vzorci chování, historickými událostmi a jejich prožíváním. Zpravidla mluvíme o mladé nastupující generaci, střední a odstupující generaci. V současné době však můžeme zaznamenat $5-6$ vedle sebe žijících generací (viz níže), protože doba časového údobí se zkracuje, jak jsme uvedli výše. Stř́íání generací je provázené sociálními (generačními) konflikty, které mohou mít různou intenzitu a podobu. Př́ćcinou konfliktů jsou rozdílné hodnotové systémy, které ovlivňují jednání prŕíslušníků generace, ale i přístup k životu, ovlivněný rozvojem techniky, sociálně ekonomickými změnami ve společnosti, ale i některými socializačními činiteli, jako jsou např̀. média apod. Generaci může ovlivnit i neobjektivní pohled mládeže na sebe samu, který v ní utvrzuje např. nešt’astné politické hodnocení typu: mládež nám přinesla převrat. $\mathrm{Na}$ proměny hodnotových orientací upozorňují např. Krivý (Krivý, V. 1998 in Ondrejkovič a kol., 2014), ale především Výzkum evropských hodnot 1991 1999 - 2008 Kusá, Z., Tížik, M. 2009 in Ondrejkovič a kol. 2014), u nás pak Sak, Semrád, Kolesárová Saková aj. Navzdory proměnám hodnotových orientací jsou určité hodnoty, které jsou nadčasové a měly by tvořit jádro hodnotových orientací bez ohledu na tu, či onu generaci., jak na to upozorňuje napřr. Jonathan Sacks v knize Důstojnost v rozdílnosti. Jak se vyhnout střetu civilizací (Triton, 2017).

Hanson a Jacog (1992 in Smith, 1999) tvrdí, obdobně jako Sak, Saková Kolesárová, nebo Ondrejkovič a Kraus, že se v dnešní době každá nová generace odlišuje svou kulturou a svými tradicemi projevujícími se ve způsobu života. V důsledku toho jsou podmínky a okolnosti, za kterých mladší generace rodičů vychovává své děti, odlišné od podmínek, za kterých oni sami byli vychováváni. Tak se může stát, že rodiče vychovávají své děti pod vlivem názorů, postojů a pomocí prostředků, které však již v čase, kdy se tyto děti stanou rodiči, mohou být překonané a $v$ očích společnosti nevyhovující, zvláště pokud se společnost řídí neprověřenými hodnotami, ale jen hodnotami aktuálními, nebo tzv. inovativními. Zejména však př̌ekonané 
se jeví nastupující generaci, protože sociální pole vnímá „aktuálníma očima“, nikoliv v historicko-společenském kontextu. $\mathrm{S}$ těmito rozpory se pak mladí rodiče vyrovnávají při výchově svých dětí. Uplatňovaný výchovný styl se pak často musí vyrovnávat $s$ těmito rozpory. Výchovný styl je utvářen několika činiteli, kterými jsou osobnost rodičủ, jejich zkušenost s výchovným stylem, osobnost dítěte a sociální prostř̌edí - mikro (úplná/neúplná rodina, kulturní podmínky, demografické podmínky, vzdělání rodičů) i makrosociální podmínky (tradice a kultura národa, etnické skupiny, sociální vrstvy, doba, politické a ekonomické vlivy). Jeho efektivita je do jisté míry dána především úrovni vztahů mezi rodiči a dětmi.

Reiss, Oliveri a Curd (1983 in Smith, 1999) uvádějí zajímavou myšlenku, že rodiče sami působí jako zprostředkovatelé společenských proměn. Vědomi si totiž změn ve společnosti pozměňují své zažité výchovné způsoby a praktiky tak, aby efektivněji připravili své děti na život $\mathrm{v}$ těchto změněných podmínkách. Kromě zážitků z vlastního dětství se tak obklopující kultura stává pro rodiče důležitým zdrojem vlastních rodičovských názorů a postojů, které se projevují v jednotlivých rodičovských praktikách (Grusec, Hastings, Mammone, 1994 in Smith, 1999). Ne vždy však rodiče zvládají nové vlivy ve společnosti zpracovat tak, aby vyústily v efektivní výchovné působení. Často se stává, že ve snaze podřídit se novodobým fenoménům ve společnosti se více dětem podbízejí, což děti nepřijímají pozitivně, i když z toho subjektivně profitují. Celková efektivita opět záleží na tom, jakou kvalitu má vzájemný vztah rodičů a dětí.

V dnešní době díky sociálně ekonomickým proměnám společnosti (restituce, obnovování rodinných firem, farem apod.) opět mluvíme o soužití více generací žijících pospolu a vedle sebe. Do jejich vztahu se však promítá skutečnost, že vyrůstali $\mathrm{v}$ odlišných sociokulturních podmínkách, byli vychováváni jiným výchovným stylem, v pojetí jiné autority (Vališová, A.) a tudíž rozdíly mezi vyznávanými hodnotami a potřebami jsou viditelnější, než $\mathrm{v}$ předchozích dobách.

Generace, které v současnosti žijí vedle sebe, jsou:

generace Z (narozená 1996 - 2010, na část této generace je zaměřen náš výzkum 13 - 15tiletí)

generace Y (narozená 1986 - 1995, nezmiňujeme v tomto článku, není na ni zaměřen náš výzkum)

generace X (narozená 1965 - 1985, rodiče zkoumaného vzorku) generace Baby Boomers (narozená 1946 - 1965), prarodiče zkoumaného vzorku) data narození jsou orientační, a jejich přesné označení se různí v řádech 5 ti let.

Nastupující generací dnes rozumíme generaci Z, která je označována jako internetová. Generace Z jsou lidé narozeni v letech 1996 - 2010. Narodili se již v digitálním světě, kde je moderní vše dokumentovat formou fotografií, tzn. „selfíček“ a vyvěšovat je na sociální sítě, jako je Facebook či Instagram. To je také často jediná jejich zábava, což má za důsledek třeba i menší až žádnou zálibu v četbě knih. (Horváthová, Bláha, Čopíková, 2016) Lidem narozených v průběhu let 1996-2010 se také rríká „Digital natives“" vzhledem 
k jejich vnímání digitálního světa. Na svět nahlížejí spíše konzumně, mají dar rychlé adaptace a stejně tak rychlého úpadku soustředění se na určitou věc či činnost. Tuto skupinu lidí lze nazvat i jako „tichá“ či „,net generation“ kvůli jejich snaze být neustále připojeni k síti. (Brončeková, 2010) Internet je skoro druhým domovem těchto lidí. Neumějí si představit život bez internetu, či vypracovat domácí úkol, samostatnou práci bez použití googlu. V této generaci platí pravidlo, kdo není online jako by nežil. (Ge-neraceY, (C) 2012).

Lidé $\mathrm{z}$ generace $\mathrm{Z}$ jsou již od mala velmi technicky šikovní a ovládají nejmodernější technologie, což jim dává značnou výhodu $\mathrm{v}$ budoucím zaměstnání. Skrz tento digitální svět, velmi rychle dospívají a specializují se $\mathrm{v}$ určitém oboru, který je zajímá. Bohužel, neznají již život bez internetu, počítače či mobilu a jiné věci, než ,jejich“ svět je nezajímá (Stašová, Slaninová, Junová, 2016). Nemají moc úctu k tradicím či zvyklostem. Věrí pouze $\mathrm{v}$ samy sebe, jsou netrpěliví, sebevědomí a sebestřední, nebojí se změn, jsou více sebeprosazujícími se, volí dravější strategie, nebojí se rizik, ale také zaměňují poznání za informace (K. P. Liessemann, 2008) Nestojí o moudra starších a spíše dají na názory svých nezkušených kamarádů. Nevydrží dlouho udržet pozornost a přednost dávají rychlosti, než kvalitě odvedené práce. Lidé generace $Z$ umějí zacházet $\mathrm{s}$ internetem a jinými nejmodernějšími technologiemi, i když často pouze na úrovni hraní elektronických her, neumí náležitě prožívat, chybí jim ale emoční inteligence. Touží po svobodě, nezávislosti, chtějí být jiní než ostatní a zároveň neustále musí sdílet své zážitky na sociálních sítích. (Horváthová, Bláha, Čopíková, 2016). Zůstávají závislí na vrstevnících, „své partě“, mají daleko k objektivizaci svých názorů. To vše se projevuje i ve způsobu trávení volného času a v zájmových aktivitách.

Jejich rodiče patří do generace $\mathrm{X}, \mathrm{V}$ době, kdy se jim rodili děti, začínali používat, či bylo již běžné pracovat s moderními technologiemi, ale ne tak rozširřené a přirozené. Nebyli ještě produktem proměny všeobecného a odborného vzdělání, kdy prvky všeobecného se stávají odborným a naopak (Skalková, 2004, Semrád a kol. 2016). Součástí této generace je i generace tzv. Husákovy děti, narozené v 70. letech 20. století.

Pojmem „Husákovy děti“ se označuje silná populační vlna, která se zvedla na počátku 70. let. Svého vrcholu dosáhla v roce 1974. Generace „Husákových dětí “ vyrůstala $\mathrm{v}$ prostředí, ve kterém nezaměstnanost neexistovala, protože byla nezákonná, nepracovat bylo trestným činem př́živnictví a udržovala se umělá zaměstnanost. Bylo to období hluboké totality a normalizace, což se promítalo i do rodin a výchovy, kde stále převažoval trend autokratického př́istupu, vyžadovala se dětská poslušnost a dominovala rodičovská kontrola. Pojetí autority ve společnosti, ve společenských skupinách, v rodině bylo zcela odlišné (viz A. Vališová)

Tito lidé zažili ještě neglobalizovaný svět a moderní technologie (počítač, mobil...) byli ještě $\mathrm{v}$ plenkách. Jejich život tolik neovlivňovali koncepty pozdní modernity (Semrád, Škrabal). V České republice vyrůstali za socialismu a po jeho odstranění najednou měli možnost cestovat a využívat svobody, která nastala. Ale na způsob výchovy a péči o své děti nedají dopustit. Z důvodu toho že vyrůstali jako děti „samy“, nebot' jejich rodiče 
byli velmi vytíženi pracovním procesem. Rovněž z důvodu, že samy byly převážně vychovávány autokratickým stylem výchovy, nedají na své děti dopustit, nastolují tzv. volnou výchovu - opečovávají je a následně je finančně podporují na vysoké škole, odstraňují jim nadměrně životní překážky. Snaží se jim poskytnout, co samy jako děti neměly -svobodu, prostor pro vyjádření, respekt, přistupují $\mathrm{k}$ nim více než partnersky. Uplatňují spíše slabé výchovné působení - $\mathrm{s}$ nízkými či žádnými nároky, $\mathrm{s}$ nedostatečnou či chybějící kontrolou jejich plnění. Rodiče ve všem dítěti vyhoví a ustupují, řeší za něj jeho problémy a nechávají vše na jeho libovůli. To samozřejmě zpětně ovlivňuje vzájemný vztah dětí a rodičů.

Zmiňme ještě krátce další silně zastoupenou generaci, a tou je Generace Baby Boomers neboli Štastná generace. Tito jedinci se narodili v letech 1946 - 1964. Vyrostli v relativně bezpečných dobách totalitního systému, zažívali převážně autokratický styl výchovy, v podobě většinou jedné „hlavy rodiny“, kterou byl zpravidla otec. V patriarchálním modelu, který přetrvával z doby Rakouska-Uherska ale i z demokratické tzv. První republiky, měl muž roli živitele, vůdce a ochránce rodiny s dominantním právem rozhodovat a řídit rodinu, vedle toho žena byla muži submisivní partnerkou, jež se starala o chod domácnosti a výchovu dětí. Na děti byly kladeny vysoké nároky, byly př́sně trestány a důsledně a přehnaně kontrolovány. Rodiče nešetřili zákazy a prŕkazy, rozhodovali za dítě a nutili ho $\mathrm{k}$ činnostem a výkonům bez ohledu na jeho potřeby a schopnosti. Byl vyžadován respekt, úcta, poslušnost. S postupným zapojováním žen do budování socialismu, vyrůstaly často děti prostřednictvím školních a mimoškolních výchovných institucí (družiny, školní kluby, zájmové kroužky, stanice mladých př́rodovědcủ, LŠU, školy $\mathrm{s}$ celodenní, případně $\mathrm{s}$ celotýdenní péčí). Rodina plnila na prvním místě funkci sociálně ekonomickou, protože pracovní proces byl upřednostňován před ostatními společenskými procesy. Usilovala i o plnění funkce socializačně výchovné, ale převážně v modelu autoritativním.

$\mathrm{S}$ moderními technologiemi tato generace prrišla do kontaktu až ve střední či pozdní dospělosti. $Z$ výše uvedeného je zřejmé, jak významné jsou změny, které nastaly ve společnosti, ale i technice, v průběhu padesáti let jednoho století, a to má výrazný vliv na vznik utváŕení mezigeneračních konfliktů, je zdrojem mnoha nepochopení, ale i podoby vzájemných vztahů jednotlivých generací. Nedorozumění často vznikají i z nesprávného pochopení role moderních technologií $\mathrm{v}$ životě člověka. Mladá generace $\mathrm{v}$ důsledku menších životních zkušeností zaměňuje $\mathrm{v}$ souvislosti $\mathrm{s}$ uplatňováním moderních technologií v životě prostředek za cíl. Digitální technologie se často stávají pro mladou generaci modlou, na základě které zanedbávají i sociální vztahy. Mladá generace ve velké míře žije svůj reálný život na sociálních sítích.

Z hlediska vývojové psychologie spadá výzkumný vzorek (děti 14-15) let našeho empirického šetření do období pubescence, které bývá zcela právem označováno za nejkritičtější, ale zároveň nejvýznamnější období v životě dítěte. Nejkritičtější a nejproblematičtější proto, že je to období bouřlivých změn, jak v úrovni fyzické, tak psychické, ale i sociální (Př́íhoda, Taxová). Díky těmto rychlým proměnám je to období velké nejistoty, která se navenek projevuje různým chováním, které je dospělou autoritou různě vnímáno a hodnoceno a často dochází $\mathrm{k}$ vnějším konfliktům s autoritou, nebo $\mathrm{k}$ vnitřním 
konfliktům uvnitř pubescenta. Proto je toto období označováno jako nejvýznamnější v životě jedince, protože si hledá svoje místo ve společnosti i samo sebe. Toto období je díky tomuto osamostatňování také spojováno $\mathrm{s}$ krizí vnější autority, vztah $\mathrm{k}$ autoritě se díky osamostatňování přirozeně mění. Historicky pojem pubescence (dospívání) se začal užívat až na začátku 20. století, kdy se začala více vnímat práva dětí. Do té doby neexistovalo období osamostatňování, dítě bylo dítětem a muselo poslouchat až do období sňatku, a pak se dívky podřizovaly svému muži, chlapci přebírali mužskou autoritu. Vztah k mladým lidem, ale zkomplikovala Úmluva o právech dětí $\mathrm{z}$ listopadu roku 1989. Dítě je $\mathrm{v}$ tomto dokumentu přijatému více jak dvěma sty zeměmi vymezováno do 18 let věku. I tento moment přispěl $\mathrm{k}$ tomu, že mladá generace je více rodinou „opečovávána“.

Generace prarodičů je ve věku od 55 let výše, což je dle Hroníka (2013) věk tradic, hodností, postavení, vlivu, ale také bohatých životních zkušeností. Jsou pro ně významné tradice a tradiční hodnoty objevovat a přibližovat se $\mathrm{k}$ nim, ale také je předávat. $\mathrm{V}$ tomto věku ubývá agresivity, individualismu a naopak přibývá tradicionalismu a otevírá se prostor pro zodpovědnou odvahu. Věk důstojnosti a moudrosti je obdobím od 65 výše (Příhoda, Sak). Toto období předpokládá projevy respektu $\mathrm{k}$ celé osobnosti i celému životnímu dílu. Člověk v tomto věku je spíše poradenský, než výkonný. Tito lidé touží mladou generaci obohatit svými zkušenostmi, znalostmi apod. Tyto vývojové potřeby jsou dnes jen těžko naplňovány, protože se naopak často setkáváme, že děti „zaučuji“ své prarodiče, ale i rodiče v používání nejmodernějších technologií. Čili to, co je pro starší generaci významné, úcta, vliv, již není mladou generací tolik prezentováno ba naopak. Mladá generace „poučuje a zacvičuje“ generaci starší, tím spíše, že téměř jakákoli činnost je dnes závislá na moderních technologiích, nejen v pracovní rovině, ale i osobní. K tomu přistupují i jazykové bariery starší generace. Pro mladší generaci je angličtina jako jazyk globalizace bližší i díky poslouchání moderní populární hudby. Dalším vlivem, který prohlubuje rozdíly mezi generacemi je proměna výchovného stylu, která je důsledkem vyššího vzdělání matek (O'Brien, 2010) a sociokulturních změn (Campbell, Gilmore, 2007), ale i názorů na výchovu, jak jsme uvedli výše. Pojetí výchovy ovšem ovlivňuje i nově orientovaný světový názor společnosti, vycházející $\mathrm{z}$ novoliberalismu.

Současní rodiče podle svých názorů použivají méně autoritářských a více demokratických a liberálních výchovných stylů ve srovnání se svými rodiči. Posun ke stylům výchovy se slabším výchovným řízením a více „kamarádským“ vztahem potvrzují i výsledky zahraničních i českých výzkumů (např. O'Brien, 2010, Gillernová, 2009 aj.).

To vše vede $\mathrm{k}$ tzv. krizi rodiny a autority, tomuto tématu se u nás věnuje nejvíce Alena Vališová, která se podílela na obou grantových projektech, dále Vlastimil Pařízek, Jarmila Skalková i Zdeněk Kolář z pohledu pedagogického a dále napřr. Petr Sak z hlediska sociologického. V současné době se tématu autority věnoval projekt Grantové agentury České republiky ( .406/03/1475) s názvem „Relativizace autority a její dopad na současnou mládež“, který probíhal v letech 2003 až 2005. Vznikl především v návaznosti na výsledky grantového úkolu Univerzity Karlovy (85/97/A- 
PP/FF . 7085) na téma „Autorita jako pedagogický problém - pojetí autority $\mathrm{v}$ pedagogické interakci učitel a žák $\mathrm{v}$ období transformace českého školství." V poslední době výrazně $\mathrm{k}$ analýze rodiny přispělo řešení projektu ESF „Rozvoj a podpora multidisciplinárního vědecko-výzkumného týmu pro studium současné rodiny na UHK (Rodina-UHK)“, CZ.1.07/2.3.00/20.0209. $Z$ výstupů tohoto projektu, je třeba uvést zejména publikaci Krause, B. et al. Životní styl současné české rodiny a publikace Nová generace autorek Stašové, L., Slaninové, G. A Junové, I. ( Gaudeamus, Hradec Králové, 2015).

Dle Ondrejkoviče (2014) ambivalentnost se stává ústřední životním paradigmatem mladé nastupující generace. Ambivalentnost, která vyplývá $\mathrm{z}$ nárůstu možností, které mladá generace má, $\mathrm{z}$ procesu individualizace a osamostatňování, ze ztráty tradičních jistot a hodnot, což je na jedné straně velmi pozitivní, ale na straně druhé to přináší nejistoty, nutnost překonávat stále složitější a komplexnější úkoly v životě, a to bez opory v předchozích formách socializace. To může vést na straně druhé ke vzniku dezintegrace, znejistění, nárůstu násilí a užívání drog, obává se Ondrejkovič (2014).

Tento vývoj nelze zvrátit, je důsledkem procesu individualizace mládeže a má charakter globálního světového fenoménu. Důležité je tedy poznat podrobně potřeby, hodnoty, postoje a názory mladé generace a připravit se, abychom mohli alespoň trochu tento vývoj kontrolovat, předvídat některé negativní důsledky a zmírnovat je a také vytvořit nastupující generaci takové podmínky, které budou odpovídat jejich potřebám, jak v oblasti vzdělávání, tak na pracovním trhu. Optimální fungování společnosti vyžaduje optimální a efektivní fungování vedle sebe žijících generací.

Naše empirické šetření se proto zaměřilo na pojetí vztahu mladé generace ke starší generaci. Provedené empirické šetření bylo kvantitativní povahy. Použili jsme jednoduché otázky. Většina otázek byla uzavřených s nabízenými odpověd'mi. Ve shodě s jinými autory (Hamplová, 2004, s. 13) jsme toho názoru, že i hrubý výzkumný nástroj může smysluplně postihnout podstatu sledovaného jevu, $v$ našem př́padě povahu vztahů mladé a starší generace. Dětem ve věku 13- 14 let bylo proto položeno celkem 18 otázek. Prvních 8 otázek bylo spíše demografické povahy. Ostatní otázky byly zaměřeny na sledovanou problematiku. Vzorek respondentů čítal více jak 400 dětí ze ZŠ Ústeckého kraje, Pardubického a Zlínského kraje. Poslední skupina byla ze Slovenska z okolí Trnavy. Sběr empirických dat probíhal v období 2015-2016.

$\mathrm{Na}$ otázku „Jak si vážím lidí starších, než jsem já?“, převážná většina respondentů (85\%) uvedla, že si starších lidí váží proto, že jim dokáží vždy pomoci. Mladí lidé si zřejmě uvědomují, že naše společnost nabízí mladým lidem velké možnosti, ale na druhé straně jsou mladí lidé vystaveni i velkému tlaku vyplývajícímu z fungování společnosti. A proto zřejmě oceňuji na starší generaci, když jim poskytne určitou oporu, včetně té materiální. Hned za uvedeným názorem se umístilo stanovisko (78\%), že si děti starších lidí váží proto, že si dokázali nalézt svoje místo ve společnosti. Odpověd’ tohoto typu úzce souvisí $\mathrm{s}$ předchozím stanoviskem. Na třetím místě pomyslného žebříčku se pak objevil názor, že si mladí váží starší generace (66\%), protože si dokáží vydělat peníze a koupit si, co se jim líbí. Tento názor koresponduje 
s názorem umístěným na 5. místě žebříčku (54\%), kde důvodem, proč si mladí váží starší generace je, že si starší generace dokáže užívat života a nic jim není na překážku. S hédonismem se mládí setkává ve svém okolí v hojné míře díky masovým sdělovacím prostředkům. Zdůrazňování hedonismu souvisí i s přehnanou ekonomizací společnosti. Bez zajímavosti není ani druhá polovina žebrríčku názorů, kde se cca s 20 \% výskytem objevily názory, že si mladí neváží starší generace, protože nemají smysl pro humor, nedokážou prosadit svůj názor, stát si za ním a často mění názory. I když tento názor není tolik zastoupen, přece jenom ukazuje na určité napětí mezi mladší a starší generací, které ovšem existuje v každé době a není ničím zvláštním v době, kterou žijeme. Může souviset i s vyšším sebehodnocením mladé generace, které je ovšem vždy s mládím spojené.

Na další otevřenou otázku: „, Lidé starší než jsem já, jsou pro mě...“, jsme nejvíce odpovědí získali (86\%) odpovědi typu „, jsou pro mě prátelé, kteří mně vždy pomohou“ $\mathrm{Na}$ druhém místě jsme zaznamenali odpověd' typu: ,jsou pro mě ochránci a oporou“. Na třetím místě se objevila odpověd'. ,jsou to lidé s životními zkušenostmi, s přehledem, kteří se umí ve složitých situacích dobře orientovat a správně rozhodnout". Na dalších místech se se objevují názory typu: „lidé, kteří zajišt’ují obživu pro členy rodiny a jsou vzorem pro můj život v dospělosti“. Z negativních odpovědí na danou otázku uvádíme ty, které se vyskytly v rozpětí 30-35\%: „, nevážím si jich, jsou to lidé zatížení minulostí. Lidé, kteří moralizují, jsou překážkou v uskutečnění mých představ o životě. Odpovědi na tuto otázku korespondují s odpověd'mi na otázku předchozí a komentár̆ by byl obdobný.

Dále nás zajímalo, co bylo těžištěm výchovy mladé generace v rodinách, na co kladli rodiče důraz ve výchově svých dětí. K našemu překvapení na otázku k čemu děti rodiče vedli, jsme získali nejvíce odpovědí $(86 \%)$ k lásce ke zvířatům. Hned na druhém místě se objevila odpověd' $(83 \%)$, dobře plnit své povinnosti“. Třetí pozici zaujala odpověd”: „ke krásám přírody a domova“ (81 \%). Zaznamenali jsme ovšem i názor, nikoliv zanedbatelný $(56 \%)$, že rodiče je vždy vedli ke krásám ze zisku něčeho nového, hmatatelného“. Celkově se ve výchovném stylu rodiny potvrdila liberalizační tendence spojená $\mathrm{s}$ akcentací sociálně ekonomické funkce rodiny a s celkovou liberalizací společnosti. Výchovný styl pak nesouvisí s výší a typem vzdělání rodičů.

Rovněž nás zajímalo, jakým činnostem se děti ve věku 13-14 let převážně věnují a co by podle jejich představ jim stačilo ke štěstí. Pokud jde o činnosti, jednoznačně převažuje sport (téměř $38 \%$ ). Na druhém místě se objevují se značnou ztrátou $(20,5 \%)$ esteticko-umělecké činnosti. Na třetím místě se objevují počítače, videohry, internet $(11 \%)$, i když překvapivě v nízkém zastoupení. Když se hovoří o kybergeneraci (SAK, 2018) předpokládali bychom, že vysoké procento mládeže se bude věnovat digitálním technologiím v nejrůznějších formách. Velmi nízkou hodnotu jsme zaznamenali i u činností, které jsou spjaté s rodinou a jejím fungováním, např. společné trávení volného času $(0.2 \%)$. Nejvíce nás však překvapilo, že vysoké procento respondentů neuvedlo žádnou konkrétní činnost, kterou by se systematicky zabývalo (téměř $60 \%$ ). Svědčí to zřjejmě o vysokém \% nevyhraněnosti zájmu 13 - 14 letých dětí, což je známou skutečností, možná 
však, že je to i důsledek stále se zrychlujícího života společnosti a neschopnosti mládeže $\mathrm{v}$ takovýchto podmínkách se soustředit na „výběr“ objektu zájmu.

Ke štěstí by námi zkoumané mládeži stačila milující, zdravá, št’astná rodina, bez hádek a s rodiči $(33,1 \%)$. Na 2. - 3. místě se pak objevují odpovědi. ", dobří přátelé a kamarádi, láska př́ítele, př́itelkyně $(13 \%)$. Ale hned na 4 . místě jsme zaznamenali odpověd' $(9,1 \%$ - finanční a materiální zabezpečení. Konkrétní představa pak schází téměř $9 \%$ respondentů.

Naše empirické šetření nepotvrdilo hypotézy 1. a 2., že pro mládež je starší generace skupinou občanů, kteři již mají život za sebou a jsou překážkou v uskutečňování jejich představ o životě. Potvrdily se však hypotézy 3. a 4. Výsledky, které jsme obdržely, svědčí o tom, že i když to tak na první pohled v reálném životě nevypadá, většina mladé generace má pozitivní vztah ke starší generaci a to i přes rozdílnost zkušeností a faktorů, které tyto generace formovaly (nejsilnějším faktorem mladé generace je virtuální realita). I když s určitými výhradami, pro většinu třináctileté a čtrnáctileté mládeže jsou starší generace pro ně vzorem. Asi zcela nemůžeme být spokojeni s motivací, která některé mladé lidi vede $\mathrm{k}$ tomu, že ve starší generaci vidí svůj vzor. Silnější materialistická orientace současné společnosti a se promítá i do vztahů mladé a starší generace. Mladá generace se přiznává, že ve starší generaci má jisté materiální zázemí, oporu a ochranu. Strach ze stále sílících teroristických útoků na evropském kontinentě vede společnost $\mathrm{k}$ řadě bezpečnostních opatření. Nebezpečí vnímá i mládež, ale zejména jejich rodiče. V důsledku toho zejména současná rodina plní až nadměrně ochranitelskou funkci. I když konání rodiny je na jednu stranu pochopitelné, nebot' $\mathrm{v}$ současné společnosti čeká na děti a mládež v každodenním životě mnoho nástrah, na druhé straně svým počínáním ovlivňuje míru sociální zralosti mladých lidí a jejich aktivitu. Větší závislost na rodičích a prarodičích pak možná vede i $\mathrm{k}$ napjatějším vztahům mezi mladou a starší generací, což se odráží ve výrocích respondentů, že ke štěstí by jim stačilo, kdyby rodina fungovala bez hádek.

Do jisté míry překvapením pro nás bylo, že v utváření hodnotové orientace kladou rodiče, podle výroků respondentů, velký důraz na vztah mladé generace $\mathrm{k}$ fauně a flóře, přinejmenším stejně tak velký jako na vztah $\mathrm{k}$ dobrému plnění povinností a vztahu $\mathrm{k}$ domovu. Výsledky možná byly ovlivněny skutečností, že většina respondentů pocházela $z$ menších měst, městysů a vesnic, tedy $z$ lokalit, kde je těsnější vazba člověka na fóru a faunu. Mezi respondenty nebylo zastoupení z měst a obcí nad 20 tisíc obyvatel. Na druhé straně zřejmě obecně ve společnosti zakotvilo povědomí o důsledcích, které pro společnost mají lidská jednání, kterými se významně mění ekosystémy planety Země. A tak jsou získané poznatky možná i výsledkem dlouhodobé snahy společnosti uvědomit si, že člověk pokud nebude citlivý k ekologickým otázkám, připravuje svým nešetrným chováním postupný zánik společnosti.

Překvapivé pro autory bylo zjištění, že v mladé generaci, která je někdy označována jako kybergenerace (Sak, 2018) se neobjevuje větši \% mládeže, která by svůj volný čas věnovala činnostem spjatým s digitálními technologiemi. I v tomto bodě se možná projevuje profil respondentů, včetně 
lokalit z nichž pocházeli. Mladí lidé se zřejmě chápou jako uživatelé digitálních technologií, ale asi se necítí s nimi hlouběji spjati a nevěnují jim pozornost jako objektu svých zájmů. Více znepokojující je však skutečnost, že více jak polovina respondentů se nevěnuje systematicky a pravidelně nějaké činnosti, která by byla předmětem jejich hlubšího zájmu. To svědčí o malé zakotvenosti osobností 13-14 letých dětí.

Autoři studie nezaznamenali významnější vazbu mezi povahou vztahu mezi mladší a starší generací, způsobem výchovy a činnostmi mládeže ve volném čase.

\section{Bibliographic references}

BLAHA, J. - COPIKOVA, A. - HORVATHOVA, P., 2016, Rizeni lidskych zdroju. Nove trendy, 1. vydani, Praha: Management Press, pocet stran 240, ISBN 978-80-7261-430-1

BRONCEKOVÁ, K., 2010, X,Y,Z - tri pismena, tri nejvyraznejsi generace soucasnosti. HRforum [on-line]. [cit. 26. 11. 2016]. Available online: http://www.hrforum.cz/x-y-z-tri-pismena-tri-nejvyraznejsi-generacesoucasnosti/

CAMPBELL, J. - GILMORE, L. Intergenerational continuities and discontinuities in parenting styles. Australian Journal of Psychology [online]. 2007, roc. 59, c. 3, s. 140-150. [cit. 13. kvetna 2011]. Available online: http://dx.doi.org/10.1080/00049530701449471

CAP, J. Styly rodinne vychovy. Psychologie dnes: casopis pro moderni psychologii, 1999 , roc. 5, c. 8, s. 23-25. ISSN 1211-5886

GILLERNOV, I. Edukacni interakce rodicu a deti a jeji promeny $\mathrm{v}$ reflexi dospivajicich. Ceskoslovenska psychologie: casopis pro psychologickou theorii a praxi, 2009, roc. 53, c. 3, s. 209-223. ISSN 0009062X.

HRONIK, F. Jak se nespalit pri vyberu zamestnancu. Motiv Press 2013. ISBN 8072261614

O'BRIEN, H. G. The Intergenerational Transmission of Parenting Styles of Irish immigrant Mothers. Journal of Family Social Work [online]. 2010, roc. 13 , c. 5, s. 395-409. [cit. 13. kvetna 2011]. Available online: http://dx.doi.org/10.1080/10522158.2010.514680

ONDREJKOVIC, P. a kol. Medzigeneracne vazby $\mathrm{v}$ sucasnej rodine. Vysledky sociologickeho vyskumu v Nitrianskom kraji. Studio Noa, Katowice 2014. ISBN 978-83-60071-74-8.

SMITH, C. A. (ed.)The encyclopedia of parenting theory and research. Westport, Conn: Greenwood Press, 1999. ISBN 0313296995

GENERACE Y: Zjisti, jake si generace [online]. (C) 2012 [cit. 26. 11. 2016]. Available online: http://www.generacey.cz/zjisti-jaka-jsi-generace

PhDr. Lenka Emrová.

Charles University

Faculty of Letters

Department of psychology

Celetná 20, 11642 Prague

Czech Republic

lenka.emrova@seznam.cz 
PhDr. Blanka Jirkovská, PhD

Doc. PhDr. Jiří Semrád, CSc,

ČVUT, Institute of Masaryk's higher studies

Department of educational and psychological studies

Kolejní 2637/2a, 16000 Prague 6

Czech Republic

Blanka.Jirkovska.@cvut.cz

Jiri.Semrad@cvut.cz 